\title{
Demarcation area between juvenile and mature wood in Elaeocarpus angustifolius
}

\author{
ISTIE RAHAYU ${ }^{1, \vartheta}$, GILANG DWI LAKSONO ${ }^{2, v v}$, WAYAN DARMAWAN ${ }^{1}$, AKHIRUDDIN MADDU ${ }^{3}$, \\ ESTI PRIHATINI ${ }^{1}$ \\ ${ }^{1}$ Department of Forest Products, Faculty of Forestry and Environment, Institut Pertanian Bogor. Jl. Ulin Lingkar Akademik, Dramaga, Bogor 16680, \\ West Java, Indonesia. Tel.: +62-251-8621285, Fax.: +62-251-8621256, `email: istiesr@apps.ipb.ac.id \\ ${ }^{2}$ Department of Forest Product Science and Technology, Faculty of Forestry and Environment, Institut Pertanian Bogor. Jl. Ulin Lingkar Akademik, \\ Dramaga, Bogor 16680, West Java, Indonesia. Tel.: +62-251-8621285, Fax.: +62-251-8621256, `»email: gilanglksno@gmail.com \\ ${ }^{3}$ Department of Physics, Faculty of Mathematics and Natural Sciences, Institut Pertanian Bogor. J1. Meranti, Dramaga, Bogor 16680, West Java, \\ Indonesia
}

Manuscript received: 26 December 2020. Revision accepted: 17 April 2021.

\begin{abstract}
Rahayu I, Laksono GD, Darmawan W, Maddu A, Prihatini E. 2021. Demarcation area between juvenile and mature wood in Elaeocarpus angustifolius. Biodiversitas 22: 2583-2590. Wood for use in building and industrial materials is generally supplied from plantations and natural forests. Timber demand has been increasing as the population grows, but the availability of timber from natural forests is declining. Therefore, to meet timber needs, wood from community forests is becoming a solution. Community forests are widely planted with fast-growing trees, such as Elaeocarpus angustifolius Blume. It offers the advantages of a short cutting cycle and large-diameter wood. This study aimed to determine the demarcation area between juvenile and mature wood on 6-year-old $E$. angustifolius based on anatomical, physical, and mechanical properties. The parameters used to determine the demarcation area included the following properties: anatomical (fiber length, cell wall thickness, and microfibril angle [MFA]), physical (moisture content and green density), and mechanical (modulus of elasticity [MOE], modulus of rupture [MOR], and hardness). Those parameters were measured from pith to bark. Data analyses were based on segmented linear regression models using PROC NLIN in SAS. Fiber length, cell wall thickness, green density, MOE, MOR, and hardness values increased from pith to bark. Results from the segmented linear regression models on anatomical properties allowed extrapolating that mature wood would begin at the $18 \mathrm{~cm}$ (based on fiber length), the $20 \mathrm{~cm}$ (based on cell wall thickness), and the $21 \mathrm{~cm}$ (based on MFA) distance from the pith. the proportion of juvenile wood in $E$. angustifolius was $100 \%$. Fiber length, cell wall thickness, and MFA can be used to determine the transition point of juvenile wood and mature wood in E. angustifolius.
\end{abstract}

Keywords: Anatomical properties, cell wall thickness, Elaeocarpus angustifolius, fiber length, microfibril angle

\section{INTRODUCTION}

Wood for use in building and industrial materials is generally supplied from plantations and natural forests. Timber demand has been increasing as the population grows, but the availability of timber from natural forests is declining. Therefore, in order to meet timber needs, wood from community forests is becoming a solution. Community forests are widely planted with fast-growing trees, such as Elaeocarpus angustifolius Blume. The advantages of fast-growing trees are a short cutting cycle and large-diameter timber. E. angustifolius as known as ganitri wood is categorized as fast-growing tree species with a large diameter. The height and diameter growth per year are 3-4 $\mathrm{m}$ and 3-4 $\mathrm{cm}$, subsequently. The trees reach a height of 25-30 m and a diameter of 30-40 cm (Rachman 2012).

The ganitri trees in Indonesia are found in Java, West Sumatra, South Sumatra (Palembang), Aceh, Timor, Lombok to Sumbawa (Heyne 1987). In West Java, ganitri is widely available in Cicalengka, Bandung, Tasikmalaya, Sukabumi, Pangandaran and Cimerak (Rachman 2012). Ganitri trees are also found in the lowland forests of
Bodogol, Gede Pangrango National Park, Sukabumi, West Java (Rahayu et al. 2012), in Nepal and India (Jain et al. 2014). The seed/fruit of the ganitri tree is used for jewelry products and the wood for carpentry, and the trees themselves are grown as shade trees along roads and highways (urban forest). Ganitri timber generally has a low percentage of mature wood and a high percentage of juvenile wood (Pandit and Kurniawan 2008).

Variation along radial direction is most studied within tree variability in wood, which is generally as a radial pattern of change in wood characteristics of juvenile and mature wood. The radial changes in wood properties vary in growth and different types of wood (Uetimane and Ali 2011; Ishiguri et al. 2011). Juvenile wood is xylem that results from the prolonged influence of the apical meristems in the region of the active crown on wood formation by the cambium during the years of early growth (Panshin and de Zeeuw 1980). Juvenile wood is made of smaller and shorter fibers with thinner walls and large microfibril angles, lower density and lower strength properties (Gryc et al. 2011). The quality of juvenile wood is lower than that of mature wood. Thus, juvenile wood is not suitable for structural purposes (Bowyer et al. 2007). 
Therefore, identifying the demarcation area between juvenile wood and mature wood in ganitri wood is necessary.

Several methods have been used to determine the demarcation area between juvenile and mature fastgrowing wood of Falcataria moluccana, Anthocephalus cadamba, and Tectona grandis wood, including segmented linear regression (Darmawan et al. 2013, 2015; Rahayu et al. 2014), visual interpretation, and polynomial regression. According to Alteyrac et al. (2006), the demarcation area can be estimated based on the density, growth ring width, and growth ring density. In the current study, the basic properties from pith to bark were analyzed to determine the demarcation area between juvenile and mature wood. The parameters included the anatomy (fiber length, cell wall thickness, microfibril angle [MFA]), physical properties (moisture content and green density), and mechanical properties (modulus of elasticity [MOE], modulus of rupture [MOE], hardness).

According to Darmawan et al. (2013) and Rahayu et al. (2014) who determine juvenile and mature wood in Falcataria moluccana and Anthocephalus cadamba wood, physical and mechanical properties (moisture content and density) was not considered as reliable parameters. This study aimed to determine the demarcation area between juvenile and mature wood on 6-years-old E. angustifolius based on anatomical, physical, and mechanical properties.

\section{MATERIALS AND METHODS}

\section{Plant materials}

Three of 6-years-old ganitri trees taken from community forest (cultivated) in Sukabumi (West Java, Indonesia) which has a rainy season throughout the year with a branch-free height of 7-9 $\mathrm{m}$, diameter at breast height of 34-36 cm, and no visible growth rings used in this study.

\section{Procedure}

\section{Test sample preparation}

The preparation of the test sample was adopted from Darmawan et al. (2013, 2015) and Rahayu et al. (2014). Three ganitri trees were cut into $5 \mathrm{~cm}$ thick discs (Figure 1.A1) and $47 \mathrm{~cm}$ long logs (Figure 1.B1). The discs had a $34-36 \mathrm{~cm}$ diameter and were cut from the trunk at $130 \mathrm{~cm}$ above the ground. These discs were used to analyze the anatomical properties (fiber length, cell wall thickness, and MFA) (Figure 1.A2) and physical properties (moisture content and green density) (Figure 1.A3). Samples for anatomical properties were cut at $1 \mathrm{~cm}$ intervals, for physical properties were cut at $2 \mathrm{~cm}$ intervals and for mechanical properties were cut an $2.5 \mathrm{~cm}$ intervals from the pith to the bark then those samples were numbered consecutively. The $41 \mathrm{~cm}$ long logs were cut lengthwise into boards from the pith to the bark (Figure 1.B2). These samples were used for testing the mechanical properties of the wood.

\section{Fiber dimension and MFA measurements}

Fiber dimension and MFA measurements were performed on the same sample (Figure 1.A2). Measurement of the fiber dimensions was performed using the Schultze maceration method (TAPPI 1991). Segments from pith to bark were taken from each tree. Each segment was $3 \times 2.5 \times 1 \mathrm{~cm}$ in size (longitudinal $\times$ tangential $\times$ radial; Figure 1.A2) were cut into smaller pieces (as big as matches). These were placed in a reaction tube, $10 \mathrm{ml}$ of $50 \% \mathrm{HNO}_{3}$ and $0.03 \mathrm{~g} \mathrm{KClO}_{3}$ granules were added, and the tube was then capped with aluminum foil. The tube was heated in a water bath for approximately 15 minutes at a temperature of $80-100^{\circ} \mathrm{C}$ until the color of the sample changed to white and visible fibers began to separate. Fibers that had separated were then rinsed with distilled water until acid-free. Samples were placed into clear plastic bottles and soaked in a $2 \%$ safranin solution for 6 hours. The length and cell wall thickness of 50 fibers from each segment were measured using ImageJ software and calibrated using a stage micrometer.
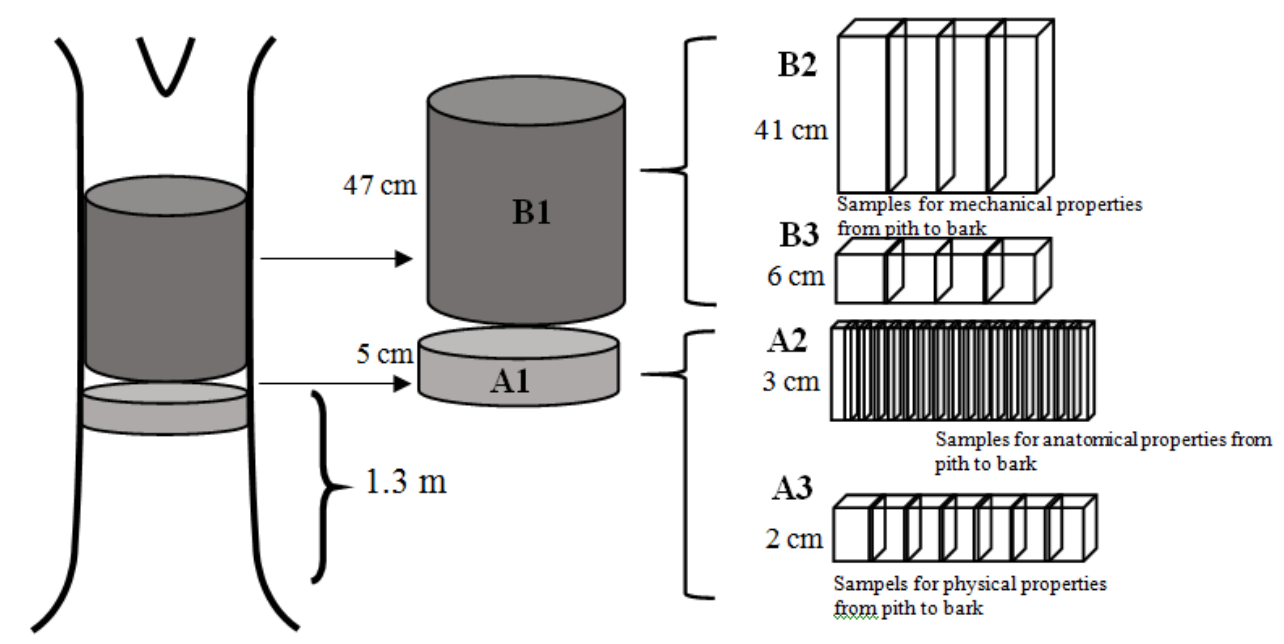

Figure 1. Schematic drawing of the sample preparation for anatomical, physical, and mechanical properties (Darmawan et al. 2013, 2015; Rahayu et al. 2014) 


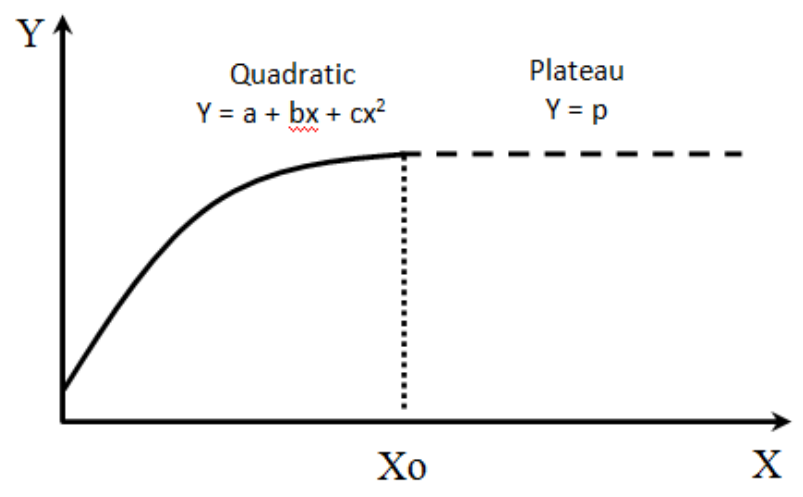

Figure 2. Fitting a segmented regression model (Darmawan et al. 2013, 2015; Rahayu et al. 2014)

The dimensions for each sample for MFA measurement were $3 \times 2.5 \times 1 \mathrm{~cm}$ (longitudinal $\times$ tangential $\times$ radial; Figure 1.A2), and samples were numbered consecutively from pith to bark, according to the segment from which they were taken. Samples were boiled in a $4: 1(\mathrm{v} / \mathrm{v})$ solution of distilled water and glycerin, and then cut into 10 to $20 \mu \mathrm{m}$ thick slices with the sliding microtome. The slices were soaked in $90 \%$ ethanol for 30 minutes and then a few drops of iodine was added for 1 minute and afterward $50 \%$ $\mathrm{HNO}_{3}$. Thirty MFA pictures were taken from each segment and later measured using ImageJ software.

\section{Physical and mechanical analyses}

Samples that were $2 \times 2 \times 2 \mathrm{~cm}$ in size (longitudinal $\times$ tangential $\times$ radial; Figure 1.A3) based on (BS-373:1957) and taken from the first segment (near the pith) to the seventh segment (near the bark) were used for measuring the physical properties, including the green density and moisture content. Samples were weighed to obtain initial weights. The samples were then placed inside a $103 \pm 2^{\circ} \mathrm{C}$ oven until they reached a constant weight. Afterward, the weights and dimensions were measured again.

The mechanical tests were carried out using the UTM based on the ASTM standard D143-94 (ASTM 2000). Tests to determine the MOE and MOR used samples that were $2.5 \times 2.5 \times 41 \mathrm{~cm}$ in size (radial $\mathrm{x}$ tangential $\mathrm{x}$ longitudinal) and the hardness that were $2 \times 2 \times 6 \mathrm{~cm}$ (radial $\mathrm{x}$ tangential $\mathrm{x}$ longitudinal) from the pith to the bark (Figure 1.B2).

\section{Data analysis}

A segmented regression model was used to determine the number of a segment where juvenile wood transitioned to mature wood. The development of anatomical properties (fiber length, cell wall thickness, and MFA) from the pith to the bark were assumed to be described by two functions of a curve. The first function is a steep slope of the curve over the first years beginning at the pith (juvenile wood), and the second function is a constant slope for the later part of the curve (mature wood). The fitted regression model for the functions takes the form of a quadratic model with a plateau (Figure 2). The change of slope in the radial fiber length, cell wall thickness, and MFA trends as a function of the number of a segment was modeled as follows Sastrosupadi (2000):

$$
Y_{i}=\mathrm{A}+\mathrm{B} X_{i}+\mathrm{C}_{i}^{2}+\mathrm{E}_{i}
$$

Where: $Y_{i}$ is the independent variable for fiber length, cell wall thickness, and MFA; $X_{i}$ is distance from pith. A is the intercept of the line of the juvenile wood; $\mathrm{B}$ and $\mathrm{C}$ are regression coefficients, and $\mathrm{E}_{i}$ is the error.

From theoretical considerations, it can be hypothesized that: (i) $y=\mathrm{a}+\mathrm{b} x+\mathrm{c} x^{2}$; if $x<x_{0}$, the quadratic equation relating $y$ and $x$; (ii) $y=\mathrm{p}$, if $x \geq x_{\mathrm{o}}$, the equation is constant (a horizontal line)

Where: $x_{0}$ is the distance from pith at which wood changes from juvenile to mature wood, and $\mathrm{p}$ is the fiber length/cell wall thickness/MFA at which wood changes from juvenile to mature wood.

With segmented regression, the statistical model (Equation 1) can simultaneously estimate parameters of the model and demarcation areas between juvenile and mature wood. The demarcation area could be directly obtained by using a nonlinear least-squares procedure (PROC NLIN [procedure nonlinear]) in SAS STAT (SAS Institute 2010), which minimizes the mean squared error. The PROC NLIN procedure in SAS was used to obtain estimates of the regression parameters and the demarcation area. PROC NLIN in SAS fit the segmented model, as shown in Figure 2. The curve in Figure 2 had to be continuous (the two sections must meet at $x_{0}$ ), and the curve must be smooth (the first derivatives concerning for to $x$ are the same at $x_{0}$ ). These conditions imply that $x_{\mathrm{o}}=-\mathrm{b} /(2 \mathrm{c})$, and $\mathrm{p}=\mathrm{a}-$ $b^{2} /(4 c)$.

\section{RESULTS AND DISCUSSION}

\section{Anatomical properties}

Fiber length

The fiber length of 6-years-old ganitri tends to increase from the pith to the bark. The average fiber lengths of $1 \mathrm{~cm}$ and $17 \mathrm{~cm}$ distance from the pith were $(855.95 \pm 82.47) \mu \mathrm{m}$ and $(1085.76 \pm 106.56) \mu \mathrm{m}$, respectively. The analysis of fiber length by segmented linear regression models indicated that the juvenile wood will end at $18 \mathrm{~cm}$ distance from the pith, after which mature wood would form. Therefore, based on the results of the fiber length analysis, the proportion of juvenile wood in fast-growing ganitri is $100 \%$ at 6-years-old (Figure 3). 


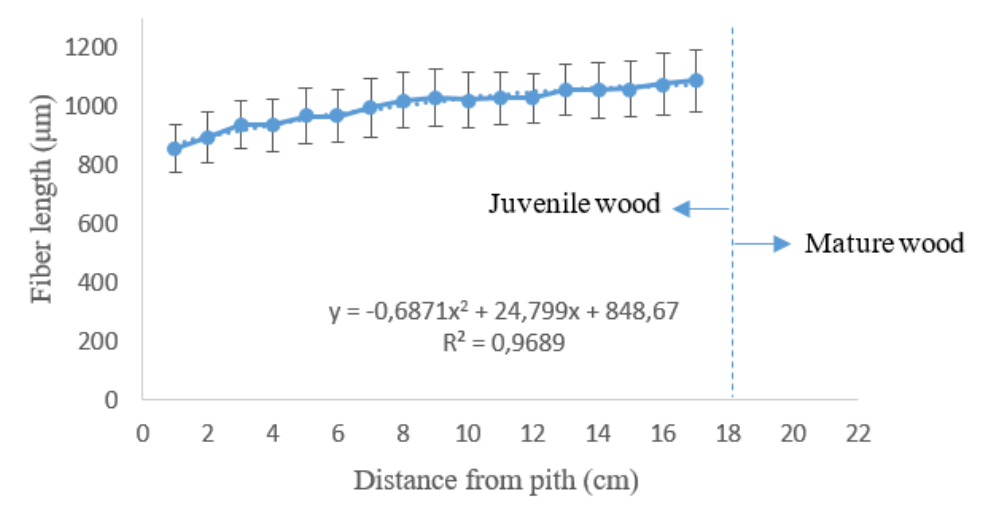

Figure 3. Fiber length average values of 6-years-old Elaeocarpus angustifolius wood from pith to bark (error bar means standard deviation of fiber length values at each distance from pith - dotted lines means the line of multiple regression equation)

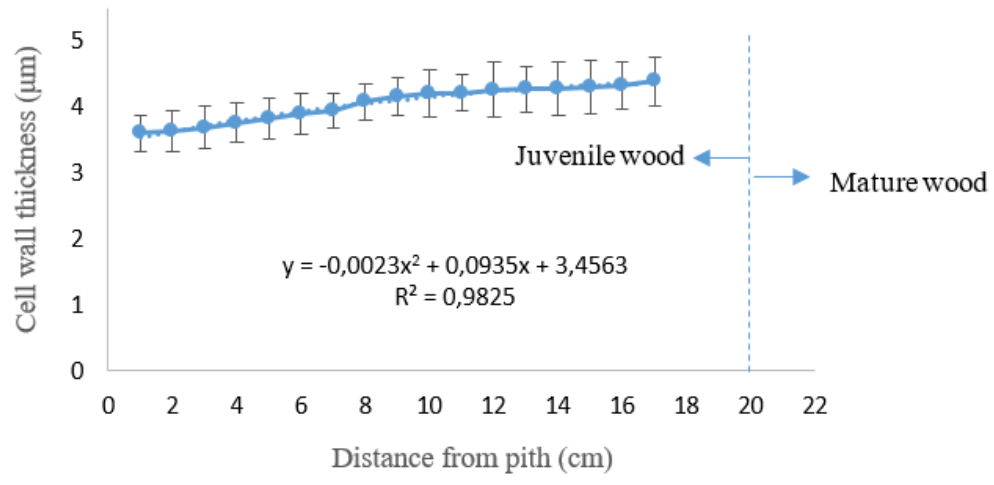

Figure 4. Cell wall thickness average values of 6-years-old Elaeocarpus angustifolius wood from pith to bark (error bar means standard deviation of cell wall thickness values at each distance from pith - dotted lines means the line of multiple regression equation)

This result is consistent with Bowyer et al. (2007), Palermo et al. (2015), and Mansfield et al. (2016), who reported that the fiber length continues to increase up until a certain segment and then remains constant closer to the bark. The results are similar to those reported by Kusumastuti (2018), who found that the average fiber length of 3-years-old ganitri was $1040 \mu \mathrm{m}$. However, research on woods which has a similar density such as benuang wood (Marbun et al. 2019), 6 years-old jabon wood (Gujar et al. 2015) and white jabon wood (Pertiwi et al. 2018) have longer values of fiber length than that of ganitri wood, which is $1599.39 \mu \mathrm{m}, 1781 \mu \mathrm{m}$, and 1520 $\mu \mathrm{m}$, subsequently.

\section{Cell wall thickness}

Cell wall thickness measurements of 6-years-old ganitri timber shows an increase as the distance increase from the pith. The average value for cell wall thickness in $1 \mathrm{~cm}$ distance from the pith was $3.60 \pm 0.27 \mu \mathrm{m}$, while the value was $4.39 \pm 0.36 \mu \mathrm{m}$ in $17 \mathrm{~cm}$ distance from the pith (Figure 4). The cell wall thickness analysis was based on segmented linear regression models, and the results indicated that the juvenile wood will end at $20 \mathrm{~cm}$ distance from the pith, with mature wood forming after that point. Therefore, based on the results for cell wall thickness, fast- growing ganitri not yet entered the stage of mature wood at 6-years-old because all parts of the wood (100\%) are still in a juvenile state.

Similar results from the pith to the bark were reported by Darmawan et al. (2013) for sengon (Falcataria moluccana) and jabon (Anthocephalus cadamba) wood. However, these results were different from other wood species which has similar density values of ganitri wood. Five-year-old jabon wood (Wistara et al. 2015) and sengon wood (Fajriani et al. 2013) were $6.46 \mu \mathrm{m}$ and $1.95 \mu \mathrm{m}$, respectively.

At the beginning of growth, cell division in the section nearest to the pith will be quick, which will generate shorter cells. Pandit and Kurniawan (2008) stated that due to the anticlinal cell division process, pith grows faster and thus generates shorter fiber and thin-walled cells. After the end of the growth period, the anticlinal division resulting in longer and thicker cell walls will result. According to Borrega et al. (2015), the increase in cell wall thickness is caused by a thicker S2 layer. Thin cell walls at the beginning of growth or young wood have a low density. However, according to Jozsa and Middleton (1994), not all species mostly on conifer species have young wood (usually the first 20-30 years of growth) with low density 


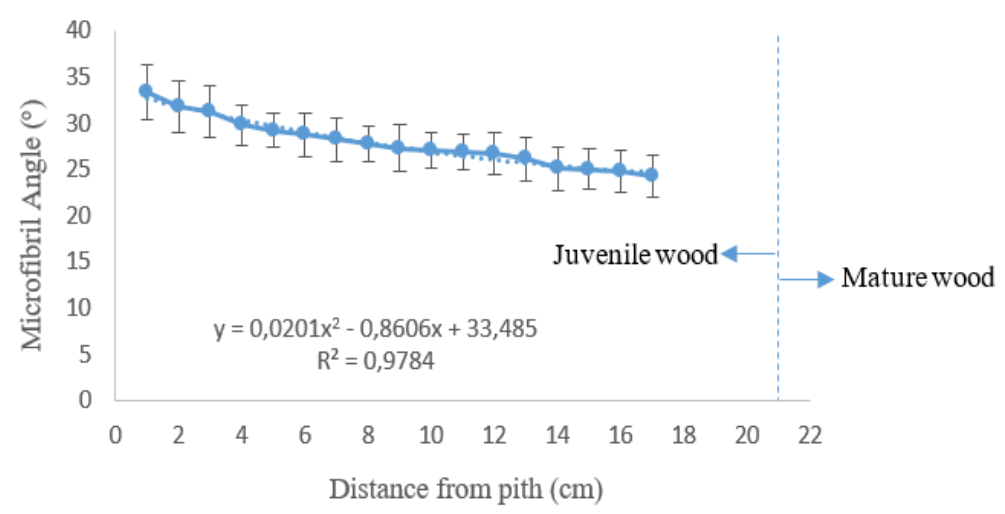

Figure 5. Microfibril angle average values of 6-years-old Elaeocarpus angustifolius wood from pith to bark (error bar means standard deviation of microfibril angle at each distance from pith - dotted lines means the line of multiple regression equation)

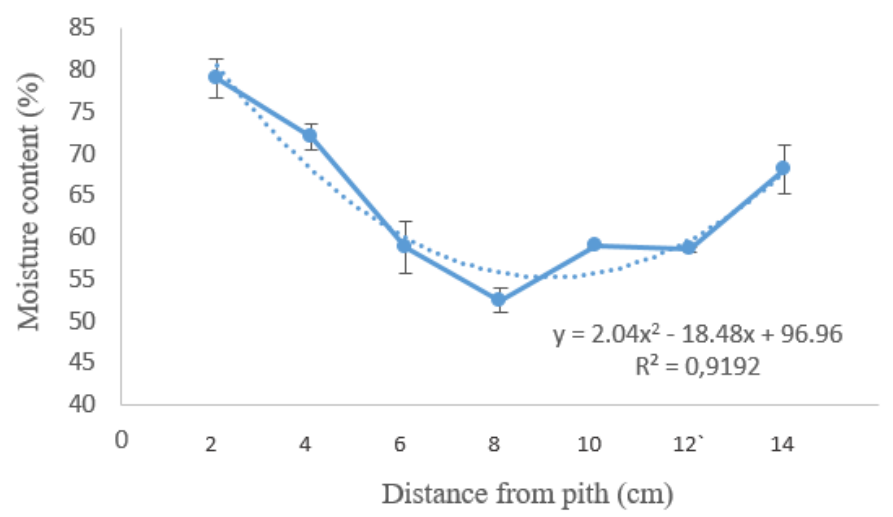

Figure 6. Moisture content average values of 6-years-old Elaeocarpus angustifolius wood from pith to bark (error bar means standard deviation of moisture content at each distance from pith - dotted lines means the line of multiple regression equation)

\section{Microfibril angle (MFA)}

The measurement results of MFA in ganitri wood in the segment near the pith $(1 \mathrm{~cm}$ distance from the pith) to the segment close to the bark $(17 \mathrm{~cm}$ distance from the pith). Visually, the average MFA value decreased from near the pith going toward the bark. The average MFA value of the $1 \mathrm{~cm}$ distance from pith was $33.35 \pm 2.89^{\circ}$ and that of the 17 $\mathrm{cm}$ distance from pith was $24.29 \pm 2.24^{\circ}$ (Figure 5). The analysis of the MFA based on segmented linear regression models indicated that the juvenile wood would end at 21 $\mathrm{cm}$ distance from the pith, and mature wood would begin to form after that point. Therefore, based on the MFA results, it can be stated that fast-growing ganitri has not yet entered the stage of mature wood at 6-years-old because all parts of the wood $(100 \%)$ are still in a juvenile state.

MFA in wood science refers to the angle of the cellulose microfibrils to the direction of the axis of the cell (Tabet and Aziz 2010). In the S2 (secondary cell wall), the orientation angle of microfibrils in juvenile wood will be greater than in mature wood. The results are consistent with findings from Darmawan et al. $(2013,2015)$ and Cahyono et al. (2015) who reported that one of the characteristics of juvenile wood transition to adult wood is the MFA decreasing from the part close to the pith toward that near the bark. Donaldson (2008) stated that the average MFA hardwood is more than $20^{\circ}$.

\section{Physical properties}

The $2 \mathrm{~cm}$ distance from the pith had a higher moisture content than the segment near the bark $(14 \mathrm{~cm}$ distance from the pith). The average moisture content of the $2 \mathrm{~cm}$ distance from the pith was $78.91 \pm 2.3 \%$, while that close to the bark (14 cm distance from the pith) was $68.09 \pm$ $2.8 \%$ (Figure 6 ). the green density gradually increased from near the pith segment $(2 \mathrm{~cm}$ distance from the pith) to close to the bark (14 $\mathrm{cm}$ distance from the pith). The average value for the density of the $2 \mathrm{~cm}$ distance from the pith was $0.69 \pm 0.016 \mathrm{~g} / \mathrm{cm}^{3}$ and that near the bark (14-cm distance from the pith) was $0.85 \pm 0.013 \mathrm{~g} / \mathrm{cm}^{3}$ (Figure 7). Moisture content and green density values from pith to bark could prove the existence of juvenile wood in 6-years-old ganitri. However, based on visual observation, those values from pith to bark are still fluctuating. Therefore, moisture content and green density are not considered as reliable parameter to determine demarcation area on ganitri. 


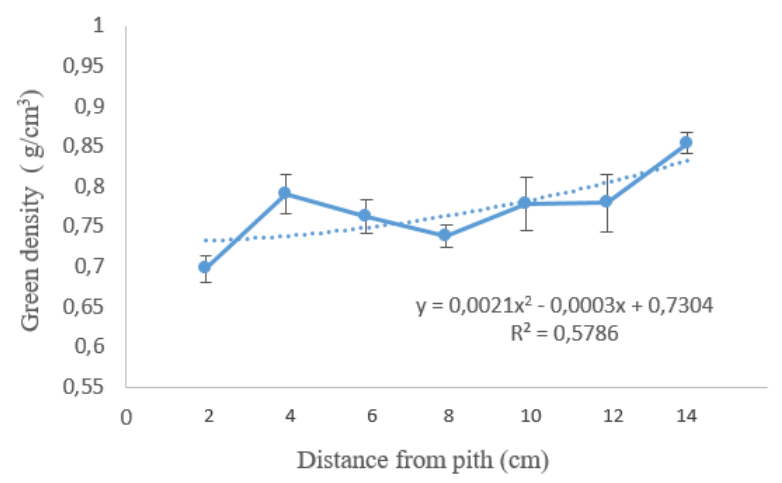

Figure 7. Green density average values of 6-years-old Elaeocarpus angustifolius wood from pith to bark (error bar means standard deviation of green density at each distance from pith - dotted lines means the line of multiple regression equation)

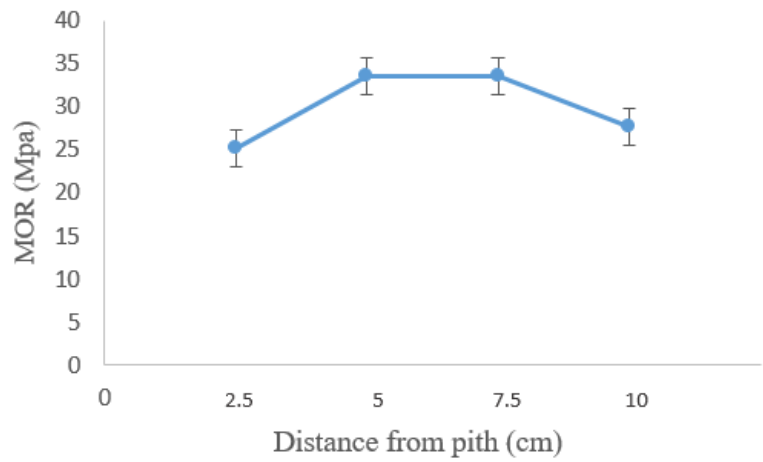

Figure 9. MOR average values of 6-years-old Elaeocarpus angustifolius wood from pith to bark (error bar means standard deviation of MOR at each distance from pith)

The hygroscopic properties of wood enable it to adjust to ambient humidity by absorbing or releasing water. According to Uar (2014), the wood near the pith has thin cell walls and lower density, which results in the amount of water in this area increasing. The results are similar to Bal et al. (2011) that the average value of moisture content decreases from the pith to the bark.

Wood density is the ratio between the mass or weight of wood to its volume, and it is expressed in kilograms per cubic $\mathrm{m}$ or $\mathrm{g}$ per cubic $\mathrm{cm}$. The average value of increasing green density from the direction of the pith to the bark in this research is by following Miranda et al. (2011) and Blohm et al. (2016). These results are similar to Bowyer et al. (2007), which indicated that the density of wood increases from the pith to the bark. Low density in the segment near the pith is likely due to the large proportion of juvenile wood in that area.

\section{Mechanical properties}

The average MOE value on a segment near the pith $(2.5$ $\mathrm{cm}$ distance from the pith) was $4618.6 \pm 370.2 \mathrm{Mpa}$, while

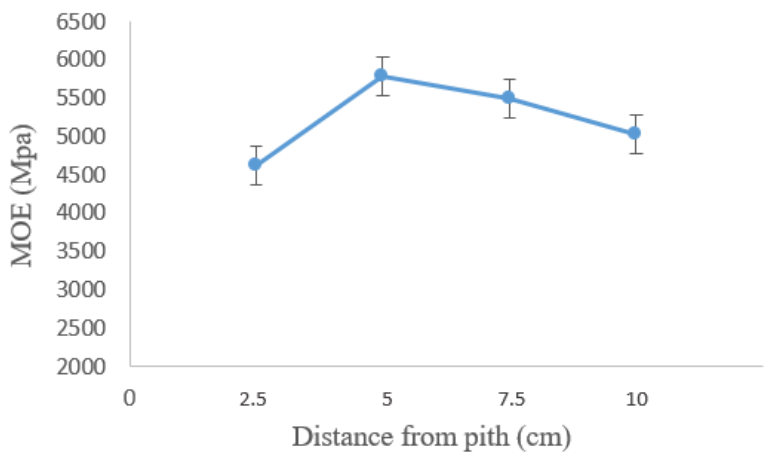

Figure 8. MOE average values of 6-years-old Elaeocarpus angustifolius wood from pith to bark (error bar means standard deviation of MOE at each distance from pith)

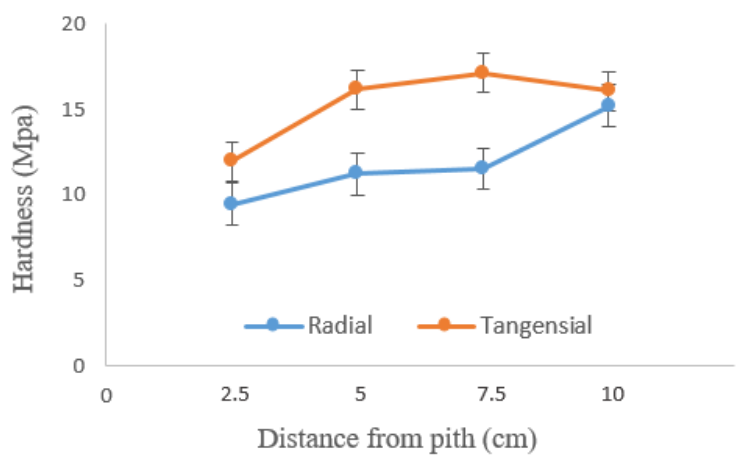

Figure 10. Hardness average values of 6-years-old Elaeocarpus angustifolius wood from pith to bark (error bar means standard deviation of hardness at each distance from pith)

the value for the segment close to the bark $(10 \mathrm{~cm}$ distance from the pith) was $5029.5 \pm 302.5 \mathrm{Mpa}$ (Figure 8). The average MOR value on a segment near the pith $(2.5-\mathrm{cm}$ distance from the pith) was $25.1 \pm 5.5 \mathrm{Mpa}$, and the value for the segment close to the bark $(10 \mathrm{~cm}$ distance from the pith) was $27.6 \pm 3.2 \mathrm{Mpa}$ (Figure 9). The tangential and radial hardness directions increase from segments near the pith to those near the bark. The average tangential and radial hardness directions values for near the pith $(2.5 \mathrm{~cm}$ distance from the pith) were $11.9 \pm 2.4 \mathrm{Mpa}$ and $9.4 \pm 3.0$ Mpa, respectively, while near the bark the values $(10 \mathrm{~cm}$ distance from the pith) were $16.0 \pm 5.8 \mathrm{Mpa}$ and $15.2 \pm 3.8$ Mpa, respectively (Figure 10). Wood hardness shows the ability of wood to resist local pressure on the wood surface. This capability is referred to as the ability to resist breakage and to withstand abrasion on the wood surface. The mechanical properties cannot be used as a parameter to determine where wood juvenile transitions to mature wood, however, they can prove the existence of the juvenile state in a segment near the pith because of low values of MOE, MOR, and hardness. 
Testing generates static bending MOE and MOR values. Wood strength can be measured by the ability of wood to maintain its original shape during being loaded. The more rigid the timber, the harder it will be to change its shape or size. Stiffness properties of wood are expressed as the MOE, while the MOR reflects the ability of the timber to withstand the maximum load. MOE and MOR are parameters for determining the quality of wood.

The results indicate that the MOE and MOR values increase from the segment near the pith towards the segment near the bark. These results are similar to Darmawan et al. (2013) in that the MOE and MOR of 7years-old sengon ( $F$. mollucana) and jabon (A. cadamba) also increased from pith to the bark. However, the results of this current research are smaller than Prihatini et al. (2020), who found the results of the MOE and MOR values of 5501.45 Mpa and 39.14 Mpa respectively.

In conclusion, based on analyses of fiber length, cell wall thickness, and MFA, mature wood can be extrapolated to begin to form at $18 \mathrm{~cm}, 20 \mathrm{~cm}$, and $21 \mathrm{~cm}$ distance from the pith, respectively. These results indicate that timber from fast-growing ganitri at 6-years-old, with a diameter of $36 \mathrm{~cm}$, is $100 \%$ juvenile wood. The parameters used for determining the transition point of juvenile wood to mature wood were fiber length, cell wall thickness, and MFA. Meanwhile, physical and mechanical parameters cannot be used for determining the transition point and can only be used to prove the existence of juvenile wood.

\section{ACKNOWLEDGEMENTS}

This research was funded by Deputy of Research Strengthen and Development of the Ministry of Research and Technology-Board of Research and Innovations (RISTEK-BRIN) Republic of Indonesia with contract no.: 1/E1/KP.PTNBH/2020 on March 18, 2020 and amandemen contract no.: 1/AMD/E1.KP.PTNBH/2020 on May 11, 2020 .

\section{REFERENCES}

Alteyrac J, Cloutier A, Zhang SY. 2006. Characterization of juvenile wood to mature wood transition age in black spruce (Picea mariana (Mill.) BSP) at different stand densities and sampling heights. Wood Sci Technol 40 (2): 124-138. DOI: 10.1007/s00226-005-0047-4

American Society for Testing and Materials [ASTM]. 2000. Annual Books of ASTM Standards. 4(10): Wood. D 143-94. Section Four. ASTM International, West Conshohocken, PN.

Bal BC, Bektas I, Tutus A, Kaymakci A. 2011. The within-tree variation in some physical properties in Eucalyptus wood (Eucalyptus grandis W. Hill ex Maiden) grown in Karabucak Region. Düzce Üniversitesi Orman Fakültesi Ormancılık Dergisi 7 (2): 82-88.

Blohm JH, Evans R, Koch G, Schmitt U. 2016. Identification and characterisation of douglas-fir (Pseudotsuga menziesii (MIRB.) Franco) juvenile and adult wood grown in Southern Germany. Drewno 59 (197): 41-47. DOI: 10.12841/wood.1644-3985.C01.05

Borrega M, Ahvenainen P, Serimaa R, Gibson L. 2015. Composition and structure of balsa (Ochroma pyramidale) wood. Wood Sci Technol 49 (2): 403-420. DOI: 10.1007/s00226-015-0700-5

Bowyer JL, Shmulsky R, Haygreen JG. 2007. Forest Products and Wood Science: An Introduction. 5th Edition. Iowa State Press, Ames, IA.

British Standard [BS-373]. 1957. Methods of Testing Small Clear Specimens of Timber.
Cahyono TD, Wahyudi I, Priadi T, Febrianto F, Darmawan W, Bahtiar ET, Ohorella S, Novriyanti E. 2015. The quality of 8 and 10 years old samama wood (Anthocephalus macrophyllus). J Indian Acad Wood Sci 12 (1): 22-28. DOI: 10.1007/s13196-015-0140-8.

Darmawan W, Nandika D, Rahayu I, Fournier M, Marchal R. 2013. Determination of juvenile and mature transition ring for fast-growing sengon and jabon wood. J Indian Acad Wood Sci 10 (1): 39-47. DOI: 10.1007/s13196-013-0091-x.

Darmawan W, Nandika D, Sari RK, Sitompul A, Rahayu I, Gardner D. 2015. Juvenile and mature wood characteristics of short and long rotation teak in Java. IAWA J 36 (4): 428-442. DOI: 10.1163/22941932-20150112.

Donaldson L. 2008. Microfibril angle: measurement, variation and relationship - a review. IAWA J 29 (4): 345-386. DOI: 10.1163/22941932-90000192.

Fajriani E, Ruelle J, Dlouha J, Fournier M, Hadi YS, Darmawan W. 2013. Radial variation of wood properties of Sengon (Paraserianthes falcataria) and Jabon (Anthocephalus cadamba). J Indian Acad of Wood Sci 10 (2): 110-117. DOI: 10.1007/s13196-013-0101-z.

Gujar M, Vishnu R, Mandan JK, Sekar I, Anoop EV. 2015. Anatomical properties of Anthocephalus cadamba (Roxb.) Miq. at different ages. Indian J For 38 (4): 323-326.

Gryc V, Vavrčík H, Horn K. 2011. Density of juvenile and mature wood of selected coniferous species. J For Sci 57 (3): 123-130. DOI: 10.17221/18/2010-JFS.

Heyne K. 1987. Useful Plants of Indonesia II. Forestry Research and Development Agency, Ministry of Forestry, Jakarta.

Ishiguri F, Wahyudi I, Takeuchi M, Takashima Y, Iizuka K, Yokota S, Yoshizawa N. 2011. Wood properties of Pericopsis mooniana grown in a plantation in Indonesia. Wood Sci 57 (3): 241-246. DOI: 10.1007/s10086-010-1163-9

Jain S, Jatwa K, Jain V, Sharma A, Mahajan SC. 2014. A review on Elaeocarpus sphaericus (Rudraksha). Pharma Tutor 2(7): 83-91.

Jozsa LA, Middleton GR. 1994. A discussion of wood quality attributes and their practical implication. Forintek Canada Corp, special publication No SP-34, Vancouver, Canada.

Kusumastuti W. 2018. Anatomical structure and dimensions of fiber in axial and radial directions ganitri wood (Elaeocarpus ganitrus Roxb.) from Wonosobo Regency. [Thesis]. Gadjah Mada University, Yogyakarta. [Indonesian]

Mansfield SD, Parish R, Ott PK, Hart JF, Goudie JW. 2016. Assessing the wood quality of interior spruce (Picea glauca $\times$ P. engelmannii): Variation in strength, relative density, microfibril angle, and fiber length. Holzforschung 70 (3): 223-234. DOI: 10.1515/hf-2015-0008

Marbun SD, Wahyudi I, Suryana J, Nawawi DS. 2019. Anatomical structures and fiber quality of four lesser-used wood species grown in Indonesia. J Korean Wood Sci Technol 47(5): 617-632. DOI: 10.5658/WOOD.2019.47.5.617.

Miranda I, Sousa V, Pereira H. 2011. Wood properties of teak (Tectona grandis) from a mature unmanaged stand in East Timor. J Wood Sci 57(3): 171-178. DOI 10.1007/s10086-010-1164-8.

Pandit IKN, Kurniawan D. 2008. Wood Anatomy: Wood Structure, Wood as Raw Material and Diagnostic Characteristics of Indonesian Timber Trade. Bogor Agricultural University, Bogor. [Indonesian]

Palermo GP de M, Latorraca JV de F, de Carvalho AM, Calonego FW, Severo ETD. 2015. Anatomical properties of Eucalyptus grandis wood and transition-age between the juvenile and mature woods. Eur J Wood Wood Prod 73 (6): 775-780. DOI: 10.1007/s00107-0150947-4

Panshin AJ, De Zeeuw C. 1980. Textbook of Wood Technology: Structure, Identification, Properties and Uses of the Commercial Woods of the United States and Canada. 4th ed. McGraw-Hill, New York.

Pertiwi YAB, AIso H, Ishiguri F, Marsoem SN, Yokota S. 2018. Radial variation of wood properties in Neolamarckia cadamba trees from an East Java community forest. South For J For Sci 80 (4): 1-9. DOI: 10.2989/20702620.2018.1463151

Prihatini E, Maddu M, Rahayu IS, Kurniati M. 2020. Basic properties of ganitri wood (Elaeocarpus sphaericus (Gaertn.) K.Schum.) from Sukabumi and its potential uses. J For Sci 14 (1): 109-118. DOI: $10.22146 /$ jik.57480

Rachman E. 2012. Study of the potential and utilization of ganitri species (Elaeocarpus spp.). Plant For Partners 7 (2): 39-50.

Rahayu I, Darmawan W, Nugroho N, Nandika D, Marchal R. 2014. Demarcation point between juvenile and mature wood in sengon 
(Falcataria moluccana) and jabon (Anthocephalus cadamba). J Trop For 26 (3): 331-339.

Rahayu M, Susiarti S, Sitohang VBL. 2012. A preliminary ethnobotanical study on useful plant by local communities on Bodogol lowland forest, Sukabumi, West Java. J Trop Biol Consev 9 (1): 115-125.

SAS Institute. 2010. SAS Procedures Guide, Vol 2, Version $6,4^{\text {th }}$ ed. SAS Institute Inc. Cary, NC.

Sastrosupadi A. 2000. Practical Experiment Design in Agriculture. Kanisius, Yogyakarta. [Indonesian]

Tabet TA, Aziz FHA. 2010. Influence of microfibril angle on thermal and dynamic mechanical properties of Acacia mangium wood using X-ray diffraction and dynamic mechanical test. Proceeding of the World Congress on Engineering, Vol II. WCW, London.
TAPPI. 1991. Tappi test methods: ash in wood and pulp (T221 om-85). Volume 1. Tappi Press, Atlanta.

Uar NI. 2014. Reliability of sonic tomography to detect agarwood in Aquilaria microcarpa Baill. J Indian Acad Wood Sci 11 (1): 65-71. DOI: $10.1007 / \mathrm{s} 13196-014-0119-x$.

Uetimane JE, Ali AH. 2011. Relationship between mechanical properties and selected anatomical features of ntholo (Pseudolachnostylis maprounaefolia). J Trop For Sci 23: 166-176.

Wistara NJ, Caroline A, Pulungan WS, Emil N, Lee SH, Kim NHI. 2015. Effect of tree age and active alkali on kraft pulping of white jabon. J Korean Wood Sci Technol 43 (5): 566-577. DOI: 10.5658/WOOD.2015.43.5.566. 